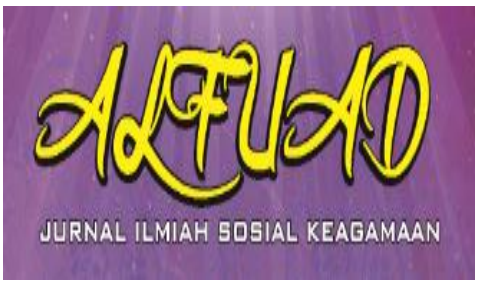

ALFUAD JOURNAL, 5 (1), 2021,(42-50)

(E-ISSN 2714-7606 P-ISSN 2614-4786 )

Available online at

http://ecampus.iainbatusangkar.ac.id/ojs/index.php/alfuad

\title{
Impact of Social Media Use on Community Psychology and Its Implications in Counseling
}

\section{Silvianetri}

Institut Agama Islam Negeri Batusangkar, Indonesia

E-mail: silvianetri@iainbatusangkar.ac.id

\begin{abstract}
: social media is a communication tool that is commonly used by everyone in today's technological era. Excessive use of social media will cause addiction, and have an impact on people's psychology. This article aims to reveal data on the impact of social media addiction on the psychology of society and its implications for counseling. The research uses qualitative research methods, especially phenomenology. The research instrument is the researcher himself, and for data collection using in-depth interviews and observation. The research respondents are the people of West Sumatra with male and female sexes aged 15 to 50 years. The data analysis technique is using Miles and Huberman data analysis with the following steps; data reduction, data display, and conclusion drawing/verification. The results of the study found that the psychological impact of social media addiction generally affects people's cognitive and emotions. The positive impact is cognitive, namely increasing insight and thinking skills, as well as giving birth to various creative ideas. The negative impact is causing forgetfulness, panic, dead-end thoughts, lack of logical thinking. Emotionally the positive impact of using social media by the community is to create happiness, optimism, motivation, enthusiasm, enthusiasm. The negative impact is causing anxiety, despair, sadness, resentment, anger and frustration. The results of this study have implications for counseling, namely preventively developing counseling techniques that aim to reduce social media addiction. Curatively, it can develop counseling techniques that can improve brain function and reduce aiety level.
\end{abstract}

Keywords: Social Media Addiction, Psychology, Counseling

\section{INTRODUCTION}

Social media is accessed globally by all people around world to seek information, express themselves, and actualize themselves. Meshi et al., (2015) argue that social media is a global phenomenon used by 2 billion people in the world. This number is not a small number, meaning that almost $25 \%$ of the world's population uses social media in their lives. This condition also exists in Indonesia. Most Indonesians use social media to communicate, access various news, and exist as socialites or artists in cyberspace. For certain people, social media is a non-daily need which as importance as primary needs. There are also people who use social media 
indefinitely. Silmi et al., (2020) stated that the average Indonesian uses social media for 8 hours 51 minutes a day. The widespread use of social media has been around since the advent of the internet. Even some people are affected by internet addiction. So that, various treatments are needed to be done for this internet addiction. Irman et al., (2019) in their study mentioned that one of treatments that can be given to reduce internet addiction is remembrance relaxation. Based on the phenomena in the field regarding the use of social media by the community, it can be seen that almost all groups and all ages access social media, not infrequently we see toddlers accessing various YouTube content. Some parents give gadgets to fussy toddlers with the aim that the toddler is not fussy anymore. Likewise teenagers' daily activities are mostly holding cellphones.

The use of social media has both positive and negative impacts. Many studies have examined positive and negative impact of social media. Bank (2015) states that social media is like two sides of a coin that can have both positive and negative impacts. The positive impact is to provide information to tourists who visit a tourist destination as well as information on the latest knowledge and discoveries. The negative impact is that people are free to convey hoax news and hate speech on social media. Dobrean \& Pasarelu (2016) conducted research on 5,126 adolescents, namely $41 \%$ of teenagers accessing news through social media like Facebook. Furthermore, data obtained on the relationship between information on social media and suicidal ideation. How dangerous it is if teenagers are not wise in using social media, because life is a challenge. There are many other dangers for social media users, especially if you use them excessively. Homewood (2017) explains the dangers of excessive use of social media, namely; disruption of self-esteem, causing distress, lack of social interaction with family and friends, fear of missing out (FOMO), insomnia and fatigue. Further research on social media was conducted by Ali (2020) on 50 students at Punjap University, data found that there was a link between social media use and student social anxiety, especially when accessing negative content. Nguyen et al., (2020) revealed that the results of their research are that there is a link between social media addiction and mental health, and it can even lead to mental disorders. Research on the use of social media was also conducted by Silmi et al., (2020) who argued that the impact of excessive use of social media would result in disruption of social interaction and impact on social anxiety. Baltac1 (2019) revealed the results of his research on 312 
university students in Turkey, in the study it was found that there was a link between addiction to social media and social anxiety and happiness. Furthermore, Dobrean and Pasarelu (2016) also stated that there is a link between news on social media and social anxiety experienced by the community.

The use of social media not only affects emotions, it also affects the brain. Sherman (2013) argues that one of the positive benefits of using social media for the brain is that the brain produces dopamine when someone accesses social media. Dopamine is a happy substance that helps boost the body's immunity. Research on the relationship between social media use and the brain was also conducted by Meshi et al (2015) expalined that the use of social media affects brain tissue, brain function, and neuro imaging. The same thing was also done by McMahon (2019) who said that excessive use of social media will affect social cognition, imitation and attention.

The various studies above provide a conclusion that the use of social media has a positive and negative impact on a person. The positive impact is that the use of appropriate social media will increase happiness and the negative impact is that it can cause social anxiety and disrupt brain function. Especially for social anxiety, it is a psychological disorder that needs to be watched out for. Okawa et al, (2021) stated that social anxiety is one of the most common mental health problems worldwide; however, the prevalence of social anxiety symptoms differed between collective and individualistic cultures. This difference may have important implications for guiding cognitivebehavioral treatment. The results revealed that there are differences in the experience of social anxiety in countries with different cultures, namely individualistic cultures and collective cultures. As for countries with individualistic cultures, namely Australia and the United States, and countries with collective cultures, namely Korea and Japan. The research sample was 704 people (279 from Australia, 137 from the United States, 101 from Korea, and 187 from Japan).

Hofmann \& DiBartolo (2010) expose general characteristics of social anxiety, namely feelings of instability, unusual attitudes, and pessimism. Ye (2021) researched about social anxiety, the results revealed that social anxiety usually begins in adolescence. Ye had 614 participants. The reult shown that social anxiety usually starts from teenagers, this needs treatment as quick as and as effective as possible. The goal is that there is no severe impact for the next stage of development. 
This social anxiety has an impact on mental health. Nemoto et al., (2020) conducted research on the relationship between social anxiety and mental illness, based on research that has been done, data on the relationship between social anxiety and schizophrenia. Dapprich et al., (2021) found results related to social anxiety, namely that social anxiety and psychopathy. These are conceptually related to the opposite of emotional, behavioral, and endocrinological endophenotypes. Each represents fear and social courage. The study used 196 healthy females as participants. This means that social anxiety has something to do with human hormones. Psychological conditions caused by these hormones have the opposite effect, namely between feelings of fear and courage. Spector et al., (2003) stated that there is a relationship between social anxiety and distress.

Researches by some experts states that there is a link between social anxiety and mental health. Social anxiety also affects brain function. Peng (2021) conducted a study on social anxiety associated with front parallel. The results revealed that there was a relationship between social anxiety and front parallel which located in the brain. The results of this study indicate that social anxiety can interfere brain function.
Based on various studies above, it can be concluded that the use of social media has an impact on community psychology. Psychology in this context means cognitive and emotional. One of the fields of science that examines society psychology of society is counseling major. Cathon \& Brownson (2000) revealed that the skills required in the field of counseling since 2014 are the ability to provide psychological services and skilled use of social media. This means that a counselor who takes part in the field of counseling should have insight and skills related to handling clients' psychological problems inclued skill in using social media. In today's technological era, all professions are required to be technology literate so that every job can be done effectively and efficiently. The use of social media by counselors in providing counseling services is also based on the behavior of clients in using social media, so that counselors can understand the positive and negative impacts of using social media by clients.

Various expert opinions and research results regarding the use of social media by the community and their impact on psychology have been described above, both theoretically and practically as well as their implications for counseling. So, the purpose of writing this article is to reveal the impact of social media use on people's 
psychology and its implications for counseling.

In introduction, authors should state the objectives of the work at the end of the introduction section. Before the objective, authors should provide an adequate background, and very short literature survey in order to record the existing solutions/method, to show which is the best of previous researches, to show the main limitation of the previous researches, to show what do you hope to achieve (to solve the limitation), and to show the scientific merit or novelties of the paper. Avoid a detailed literature survey or a summary of the results.

\section{METHOD}

This study used a qualitative approach, particularly phenomenology. Phenomenological research has certain criteria. Umanailo (2019) revealed that there are four criteria for phenomenological research, namely; description, reduction, essence and intentionality. Qutoshi (2018) argues that phenomenology is part of a qualitative method that allows researchers to apply their subjectivity and interpersonal skills in the research process. The aims is to develop a frame of mind to view a particular phenomenon or experience. Moreover, phenomenological research is suitable for social science. Respondents in this study were male and female in West Sumatra aged 15 to 50 years old. The research instrument is the researcher herself, and data collection used were indepth interviews and observation. The data analysis technique used was data analysis by Miles and Huberman (1994). The steps are; data reduction, data display, and conclusion drawing/verification.

\section{RESULT AND DISCUSSION}

In general, the results of the study found that the psychological impact of social media addiction on society has two sides, namely positive and negative impacts. The impact is related to cognitive and emotional. This study has implications for the counselor profession. The presentation of data from interviews and observations of the community related to the impact of using social media can be seen in Table 1 below.

Table 1. Data on the Psychological Impact of Social Media Use by Society

\begin{tabular}{|c|c|c|}
\hline $\mathrm{No}$ & Component & Result \\
\hline 1 & Respondents & $\begin{array}{l}\text { The respondents } \\
\text { of this study } \\
\text { were male and } \\
\text { female from } \\
\text { West Sumatra } \\
\text { aged } 15 \text { to } 50 \\
\text { years }\end{array}$ \\
\hline \multirow[t]{2}{*}{2} & $\begin{array}{l}\text { Frequently used } \\
\text { social media }\end{array}$ & $\begin{array}{l}\text { YouTube, } \\
\text { WhatsApp, } \\
\text { Facebook, } \\
\text { Instagram } \\
\text { Impact on }\end{array}$ \\
\hline & $\begin{array}{l}\text { Psychological } \\
\text { impact }\end{array}$ & $\begin{array}{l}\text { cognitive, which } \\
\text { gives positive }\end{array}$ \\
\hline
\end{tabular}




\begin{tabular}{ll}
\hline and negative \\
impacts. \\
The positive \\
impact of using \\
social media by \\
the community \\
is to increase \\
insight and \\
thinking skills, \\
as well as \\
various creative \\
ideas. \\
\\
The negative \\
impact is \\
causing \\
forgetfulness, \\
panic, dead-end \\
thoughts, and \\
lack of logical \\
thinking. \\
\\
Positive and \\
negative impacts \\
on emotions are \\
the positive \\
impact is to \\
create \\
happiness, \\
optimism, \\
motivation, \\
enthusiasm, \\
enthusiasm, \\
while he has \\
negative impact \\
is causing \\
anxiety, despair, \\
sadness, \\
resentment, \\
anger and \\
frustration. \\
\\
\end{tabular}

Based on Table 1 above, it shown the positive and negative impacts of the use of social media by the public. The impact is viewed from the use of social media by the community. Most people access social med ia from YouTube to view certain content. In general, at this time, people access news about the COVID-19 virus from various social media that are trending in Indonesia. Based on interviews, data revealed that the order of the most accessed social media is: first, namely YouTube, people like to use YouTube to update the development of the COVID-19 virus because this social media is interesting with its visuals and audio, making it easier to understand. It also has content and news. YouTube is updated all the time, even the news updates 24 hours. Not hindered by office hours and not hampered by time off. Especially for mothers, they see more cooking content and how to take care for flowers on YouTube social media. Mothers feel happy when they see the content of cooking and caring for these flowers. On the other hand, when people see the dangerous content of Covid-19, people feel afraid, sad, angry and hopeless. Furthermore, the second social media that is often used by the people of West Sumatra is WhatsApp. From WhatsApp, people see videos related to the news and impact of the Covid19virus. Furthermore, social media that is often used to find out news and the impact of the Covid-19 virus is Facebook. The younger generation reads news about Covid-19 from Instagram. The four media sequences that are often used by the people of West Sumatra above have an impact on cognitive, and emotional.

In general, social media has impact on people's cognitive and emotions. The positive impact is cognitive, namely increasing insight and thinking skills, as well as various creative ideas. The negative impact is causing forgetfulness, 
panic, dead-end thoughts, and lack of logical thinking

Emotionally the positive impact of using social media by the community is to create happiness, optimism, motivation, enthusiasm. The negative impact is causing anxiety, despair, sadness, resentment, anger and frustration.

Table 2. Implications of the Psychological Impact of using social media by the Community on Counseling

\begin{tabular}{|c|c|c|}
\hline No & $\begin{array}{l}\text { Implications of } \\
\text { Counseling }\end{array}$ & Services \\
\hline 1 & Preventive & $\begin{array}{l}\text { Developing } \\
\text { counseling } \\
\text { techniques that } \\
\text { aim to reduce } \\
\text { social media } \\
\text { addiction }\end{array}$ \\
\hline 2 & Curative & $\begin{array}{l}\text { developing } \\
\text { counseling } \\
\text { techniques that } \\
\text { can improve } \\
\text { cognitive } \\
\text { function and } \\
\text { can reduce the } \\
\text { level of } \\
\text { negative } \\
\text { emotions and } \\
\text { increase } \\
\text { positive } \\
\text { emotions }\end{array}$ \\
\hline
\end{tabular}

The implication of this research for counseling is that it can be prevented by developing counseling techniques that aim to reduce social media addiction. Curatively, it can be done by developing counseling techniques that can improve cognitive function and reduce the level of negative emotions and increase positive emotions.

There are many ways that a counselor can do to reduce positive emotions and increase negative emotions. Harris (n.d.) suggests one of the counseling approaches, namely cognitive behavior therapy which recommends relaxation techniques to reduce anxiety levels. Tamir et al., (2017) stated that to increase happiness, one must remember good and pleasant experiences.

This study provides support for counselors develop techniques for counseling services, in order to increase cognitive and positive emotions and reduce negative emotions.

\section{CONCLUSION}

The results of the study found that the psychological impact of social media addiction had both positive and negative impact. In general, these impacts people cognitive and emotions. The positive impact is cognitive, namely increasing insight and thinking skills, as well as various creative ideas. The negative impact is causing forgetfulness, panic, dead-end thoughts, and lack of logical thinking.

Emotionally the positive impact of using social media by the community is to create happiness, optimism, motivation, enthusiasm. The negative impact is causing 
anxiety, despair, sadness, resentment, anger and frustration.

The results of this study have implications for counseling, namely preventively developing counseling techniques that aim to reduce social media addiction. Curatively, it can develop counseling techniques that can improve brain function, increase positive emotions, and reduce levels of negative emotions.

\section{REFERENCES}

Ali, A., \& Professor Journalism and, A. (2020). Influence of Social Media in Developing Social Anxiety: A Study of Kurukshetra University Students. Palarch's Journal Of Archaeology Of Egypt/Egyptology., 17(12), 1585-1592.

Baltac1, Ö. (2019). The Predictive Relationships between the Social Media Addiction and Social Anxiety, Loneliness, and Happiness. International Journal of Progressive Education, 15(4), 7382. https://doi.org/10.29329/ijpe.2019. 203.6

Bank, P. C. M. Van Der. (2015). The impact of social media: advantages or disadvantages. 4(2).

Cathon, D., \& Brownson, K. (2000). Code of ethics. Hospital Materiel Management Quarterly, 22(2), 2326. https://d oi.org/10.2307/789117

Dobrean, A., \& Pasarelu, C.-R. (2016). Impact of Social Media on Social Anxiety: A Systematic Review. New Developments in Anxiety Disorders, December. https://doi.org/10.5772/65188

Harris, S. J. (n.d.). "The time to relax is when you don't have time for it."

Hofmann, S. G., \& DiBartolo, P. M. (2010). Social Anxiety Clinical,
Devepmental, and Social Perspectives. In Elsevier. https://doi.org/10.1016/C2009-001963-1

Homewood. (2017). the Dangers of Social Media on Your Mental Health It 'S No Longer Just a Cliché: We Really Are All No Matter Where. 11.

Irman, I., Saari, C. Z., Silvianetri, S., Rajab, K., \& Zalnur, M. (2019). The Effect of Zikir Relaxation in Counseling to Reduce Internet Addiction. Al-Ta Lim Journal, 26(1), 1-11. https://doi.org/10.15548/jt.v26i1.54 7

McMahon, C. (2019). The psychology of social media. The Psychology of Social Media, 1-106. https://doi.org/10.4324/978131517 0619

Meshi, D., Tamir, D. I., \& Heekeren, H. R. (2015). The Emerging Neuroscience of Social Media. Trends in Cognitive Sciences, 19(12), 771-782. https://doi.org/10.1016/j.tics.2015.0 9.004

Nemoto, T., Uchino, T., Aikawa, S., Matsuo, S., Mamiya, N., Shibasaki, Y., Wada, Y., Yamaguchi, T., Katagiri, N., Tsujino, N., Usami, T., \& Mizuno, M. (2020). Impact of changes in social anxiety on social functioning and quality of life in outpatients with schizophrenia: A naturalistic longitudinal study. Journal of Psychiatric Research, 131, 15-21. https://doi.org/10.1016/j.jpsychires. 2020.08.007

Nguyen, T. H., Lin, K. H., Rahman, F. F., Ou, J. P., \& Wong, W. K. (2020). Study of Depression, Anxiety, and Social Media Addiction Among Undergraduate Students. Journal of Management Information and Decision Science, 23(4), 284-303.

Qutoshi, S. B. (2018). Journal of 
Education and Educational Developement Discussion Phenomenology: A Philosophy and Method of Inquiry. 5(1), 215-222.

Sherman, K. (2013). How social media changes our thinking and learning. Central Piedmont Community College, 8-10.

Silmi, Z. K., Rachmawati, W. R., Sugiarto, A., \& Hastuti, T. P. (2020). Correlation of Intensity of Use of Social Media with The Level of Social Anxiety in Adolescents. Midwifery and Nursing Research, 2(2), 60-64. https://doi.org/10.31983/manr.v2i2. 5880

Spector, I. P., Pecknold, J. C., \& Libman, E. (2003). Selective attentional bias related to the noticeability aspect of anxiety symptoms in generalized social phobia. Journal of Anxiety Disorders, 17(5), 517-531. https://doi.org/10.1016/S08876185(02)00232-3

Tamir, M., Schwartz, S. H., Oishi, S., \& Kim, M. Y. (2017). The secret to happiness: Feeling good or feeling right? Journal of Experimental Psychology: General, 146(10), 1448-1459.

https://doi.org/10.1037/xge0000303

Umanailo, M. C. B. (2019). Overview of Phenomenological Research. August. https://doi.org/10.31222/osf.io/4t2f $\mathrm{v}$ 